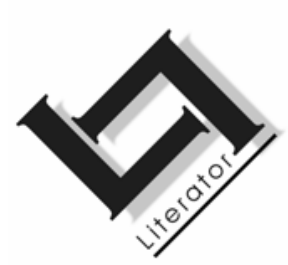

\title{
Reise in identiteit: aspekte van plek en hoort in verhale van Elsa Joubert en Riana Scheepers
}

\author{
S. Meyer \\ Vakgroep: Afrikaans \\ Fakulteit Opvoedingswetenskappe \\ Potchefstroomkampus \\ Noordwes-Universiteit \\ POTCHEFSTROOM \\ E-pos: smssm@nwu.ac.za
}

\begin{abstract}
Travels in identity: aspects of place and belonging in novels by Elsa Joubert and Riana Scheepers
\end{abstract}

An investigation into the experience of place and its changing nature in the story "Bloed" [Blood] (from Melk, [Milk] 1980) by Joubert and some stories from Scheepers' collection Die ding in die vuur [The thing in the fire] (1990) serves to establish the role of the experience of place with regard to the development of identity in these stories. In "Bloed" [Blood] the dynamic way in which the experience of place influences identity is clear: on a single day trip the main character's experience of alienation in Africa is transformed into an identification with Africa; a process that is directly related to the radically changing experience of place in the story. All the core markers of identity construction gender, class, race and sexuality - are involved in this process of re-orientation; and the simultaneous, intertextual appropriation and subversion of a classic Western poem occur in the portrayal of the powerful adaptive reaction in terms of the experience of place and identity within the post-colonial situation. Scheepers' stories: "Tweede kind" [Second child], "Drie sinvolle gesprekke" [Three meaningful conversations] and "Dom koei" [Daft cow] represent phases in the changing experience of identity that correlate with the journey of identity in "Bloed" [Blood], but the identity changes more subtly and gradually - intratextually played out over three stories - as well as less completely. The changing nature of the experience of 
place, as portrayed by means of the topographic structure of the stories and the effect of the filter-focalisation, again supports the process of a change in perspective on, and identification with Africa.

\section{Opsomming}

\section{Reise in identiteit: aspekte van plek en hoort in verhale van Elsa Joubert en Riana Scheepers}

'n Ondersoek na die belewing van plek en die veranderende aard daarvan in die verhaal "Bloed" (uit Melk, 1980) van Joubert en enkele verhale uit Scheepers se bundel Die ding in die vuur (1990) dien om vas te stel wat die rol van plekbelewing is ten opsigte van identiteitsvorming in hierdie verhale. Uit "Bloed" blyk die dinamiese wyse waarop plekbelewing identiteit beïnvloed: op 'n enkele dagreis verander die hooffiguur se ervaring van vreemdelingskap in Afrika na 'n identiteitsvereenselwiging met Afrika; 'n proses wat direk verband hou met 'n drasties veranderde belewing van plek in die verhaal. Al die kernaspekte van identiteitskonstruksie geslag, klas, ras en seksualiteit - is betrokke by hierdie heroriënteringsproses en die gelyktydige intertekstuele toeeiening en ondermyning van 'n klassieke Westerse gedig vind plaas in die uitbeelding van die kragtige aanpassingsreaksie in terme van plek- en identiteitsbelewing by die postkoloniale situasie. Scheepers se verhale "Tweede kind", "Drie sinvolle gesprekke" en "Dom koei" verteenwoordig fases in die veranderende identiteitsbelewing wat ooreenstem met die identiteitsreis in "Bloed", maar die identiteitsaanpassing vind meer subtiel en geleidelik - intratekstueel uitgespeel oor drie verhale - asook minder volledig plaas. Die veranderde aard van plekbelewing, soos uitgebeeld by wyse van die topologiese struktuur van die verhale en die effek van die filter-fokalisering, steun weereens die proses van perspektiefverandering op en identifikasie met Afrika.

\section{Inleidend}

'n Fassinerende waarheid wat spruit uit die skakels tussen ruimte en identiteit is dat soos wat ons belewing van 'n bepaalde ruimte aan verandering onderwerp word, ons identiteit deurgaans daardeur geraak word. Die ruimtes wat ons bewoon het 'n vormende invloed op ons identiteit, ${ }^{1}$ en hierdie identiteit bepaal ons waarnemings en

1 Die aspek van identiteit wat sentraal staan in hierdie ondersoek en bevestig word in die verhaalanalises wat volg, is die moontlikheid van verandering en 
weergawe van daardie ruimtes asook ons wisselende ruimtelike ervarings (Viljoen et al., 2004:12).

Volgens Ashcroft (2001:125) draai die konstruksie van die gegewe van plek ${ }^{2}$ altyd om die vraag: Waar hoort ek? Ook Hunter (1990:3) betrek die identiteitskwessie van hoort in haar omskrywing van wat sy noem "a sense of place": "The word place refers predominantly to the writers' shaping of a home-in-the-world - an individual, social, and cultural identity - for her protagonist(s)."

In hierdie ondersoek word 'n kortverhaal van Elsa Joubert en enkele verhale van Riana Scheepers gebruik om vas te stel op watter wyse(s) en tot watter mate die belewing van plek deur 'n betrokke karakter verander. Dit vorm deel van 'n groter ondersoek na die rol wat plekbelewing ten opsigte van identiteitsvorming speel in hierdie verhale.

Die resultate van die ondersoek behoort by te dra tot ons insig in die rol wat plekbelewing in die postkoloniale aanpassingsproses van 'n individu of gemeenskap kan speel. In hierdie ondersoek, waar aspekte van plek en hoort sentraal staan, word dus gefokus op wat Ashcroft (2001:125) beskou as een van die moeilikste en mees gedebatteerde kwessies in die postkoloniale ervaring.

\section{Reise in identiteit: Elsa Joubert}

Joubert se oeuvre word tematies oorheers deur die mens van Afrika, wat telkens nuwe insigte vorm omtrent sy gesplete kulturele identiteit, gevorm uit Europese, Afrika- en Oosterse wortels.

Die aanpassing in identiteit wat deur die belewing van die karakters in Joubert se werk uitgebeeld word, is ' $n$ proses wat oor dekades in haar skryfwerk plaasgevind het - 'n tydperk wat die grootste

aanpassing, soos dit ook blyk uit Whitebrook (2001:6) se omskrywing van identiteit as: "a product of ourselves or a product of our context".

2 Ashcroft (2001:125) onderskei plek baie duidelik van ligging en ruimte, wat leë plek is: "Place ... emerges out of the interaction of language, history, visual perception, spatiality and environment". Ashcroft gebruik Pierre Bourdieu se term habitus uit Bourdieu se Reproduction in education, society and culture (1972) om sy siening van plek verder te verduidelik: "(Habitus) is a term which suggests the extent to which 'place' may be seen to be a 'practice' rather than a visual, geographic or topographic location ... This practice of habitation is more than the occupying of a location, it is itself a way of being within which, and through which, place comes to be" (Ashcroft 2001:159). 
gedeelte van haar oeuvre oorspan. In Ons wag op die kaptein (1963) sowel as in Bonga (1971) vind die leser die motief van die vreemdeling-in-Afrika. In Die Nuwe Afrikaan (1975) word die reisiger se emosionele betrokkenheid by Afrika reeds uitgespel: sy is Afrikaan van herkoms, dus van instelling; sy vereenselwig haar met die problematiek van Afrika. Teen die einde van die reis in Gordel van smarag (1997) kom Joubert tot die slotsom dat die Ooste "al hoe meer die derde hoek van 'n driehoek - Holland, Afrika, die Ooste - vir ons hier aan die Kaap" word (Joubert, 1997:134). Afrikaans word uiteindelik die bindende faktor tussen die drie hoeke van dié erfenisdriehoek. Daarin, skryf sy, "is ek nie 'n tussenlander nie. Ek is tuis in my taal, en my taal is tuis in Afrika" (Joubert, 1997:149).

In die verhaal "Bloed" uit Melk (1980) gebeur die sonderlinge, naamlik die uitbeelding van die saamtrek van verskillende belewenisse van eie identiteit in die ervaring van Hester: die "identiteitmet-vertrek", wat ooreenstem met die belewing van die karakters in Joubert se werk in die sestigerjare, en 'n identiteitsbelewing wat drasties beïnvloed is tydens 'n reis en ooreenstem met dié van die karakters in haar werk sedert die middelsewentigerjare. Hierdie aanpassing in identiteitsbelewing word nie net uitgebeeld in 'n enkele verhaal nie, maar word ook ervaar binne die vertelde tydsduur van 'n enkele dag.

In Joubert se werk is die karakters se veranderde belewing van hulle eie identiteit en die nuwe perspektief op hulle toekomstaak in Afrika die resultaat van verskillende uitgangspunte tot die reis. In Suid van die wind (1962) het insig in haar identiteit gegroei uit die somtotaal van persoonlike ervarings van die reisiger met haar reisgenote tydens 'n busrit oor Madagaskar. In Die nuwe Afrikaan (1974) het dit gebeur as die resultaat van die sogenaamde interpretatiewe joernalistiek - objektiewe deurgronding van die hede (die aktuele werklikheid soos sy dit op haar reis deur Angola teëkom) en 'n vergelyking met die verlede, sê Beukes (1982:75, 167). Gordel van smarag is 'n reisverslag waar die vergelyking van ervarings die ontdekkingsproses begelei - die ervarings van Joubert op reis deur Indonesië word telkens teen dié van Leipoldt afgespieël en gemeet.

In "Bloed" dien nog 'n ander invalshoek op die gegewe van reis die doel van die verwerwing van nuwe begrip oor die wêreld wat verken word, die mense wat ontmoet word en veral die eie identiteit. In hierdie verhaal beleef Hester 'n motorreis al dieper in ' $n$ "reservaat" in tot by 'n boshospitaal waar sy in 'n droom beleef dat sy, teen haar sin, bloed skenk aan 'n ernstig beseerde man. Die fisieke ervaring 
van vertrek, reis en aankoms korreleer egter met punte op 'n ekwivalente reiservaring ten opsigte van identiteitsbelewing. Hester se reis eindig in 'n nuutsoortige ervaring van haar identiteit, direk gekoppel aan die andersoortigheid van die belewing van plek, hoewel haar dagreis haar, in terme van reisafstand, maar 'n hanetree wegneem van waar sy vertrek het.

\section{3. "Bloed" 3 (Elsa Joubert): die reis}

Viljoen (2002:21) argumenteer dat geslag, klas, ras en seksualiteit beskou kan word as die mees algemene parameters waarbinne identiteit gekonstrueer kan word, hoewel die faktore wat die konstruksie van identiteit bepaal, geweldig gevarieerd is. In "Bloed" is elk van hierdie kernaspekte in identiteitskonstruksie betrokke by die heroriënteringsproses wat Hester beleef.

\subsection{Vreemdeling by vertrek}

Aan die begin van Hester se reis in "Bloed" - 'n tog aangepak saam met haar vriend, Piet, en oom Herrie - verraai sy 'n gedistansieerdheid van die ruimte waardeur hulle reis. Sy ervaar 'n ongemak met die geilheid en dwingendheid van die Afrika-ruimte: die soelheid van die lug wat haar vel "byna wellustig aanraak" (p. 8); die bedreiging van bosse wat agter haar toesluit, haakdoringtakke wat sy voor haar moet lostrek (p. 9). "Dis vir my vreemd", kwalifiseer sy haar verwondering oor dié wêreld as 'n soort ontuisheid ( $p$. 8; kursiverings - SM).

Hester probeer om liggaamlik aan die aandrang van die bos te ontkom. Sy sukkel om oor die moerassige grond te loop, "maar sy kom daarvan los. (p. 10). Sy verset haar teen die ervaring van saamgetrek te word met die beweging van die wolke se skadu's: "Kom, sê sy vir haarself, kom terug. Sy groei weer in haar liggaam in. Sy draai weg van die bos" (p. 10; kursivering - SM).

Wanneer die motor by die winkeltjie in die bos stilhou, neem Hester die mense só waar: "By die lae deur kom swartmense uit, een op 'n keer, soos 'n mier in die son kom na die donkerte van sy ondergrondlewe" (p. 12). Die beeld van die mier met sy ondergrondse lewe en die konnotasie van lae lewensfunksie hieraan

$3 \quad$ Verwysings wat in punt 3 en sy onderafdelings slegs met 'n bladsyaanduiding gemaak word, verwys na Joubert (1980). 
geheg, is draer van die begrip primitiwiteit, op grond waarvan Hester 'n kloof ervaar tussen dié mense en haarself. Sy kry warm in die motor, maar is onwillig om deur die saamdromming van mense op die winkelstoep te loop en Piet te soek, want "nóg in die dowwe gesuis van hulle gepraat, in die skreeu van een vrou op die ander, nóg in die mond wat oopgaan in 'n skielike wit lag kan sy iets vind wat sy ken, wat sy met hulle gemeen het" (p. 12). Hester beleef my ruimte as gekultiveerd, veilig, georganiseerd, in kontras met hulle ruimte wat anders, vyandig en chaoties is.

Sy hou die transaksie van 'n hoenderhandelaar (p. 13) met 'n afstandelike geïnteresseerdheid dop en bly, ten aanskoue van die bloederige slagting van die hoender wat volg, genotvol eet aan 'n piesang.

Sy [die swart vrou] sny die nek kort onder die kop af ... Soos die lyf begin rondtrap, spuit die bloed. Dit spuit op die vlerke wat fladder, op die grond, op die klere van kinders wat nader staan; dit spuit vir laas op die voete van die vrou.

Hester se sluk ontvang die pap piesangmoes. Die geur kleef aan haar verhelmelte, aan haar lippe. Onbewus vee haar tong haar lippe skoon (p. 13).

By die boshospitaal dwing die hitte van die middaguur Hester ook na die skadu's van die bome waar die mense sit. Sy ervaar weer 'n afsydigheid teenoor hulle; die kontak met kinders wat oor haar kruip en "klou met bleek palms" is vir haar benouend: "Sy voel die sweet afloop van die aanraking tussen hulle hande en haar vel; sy trek moeisaam haar voete los" (p. 18). Ook van die pasiënte neem Hester op 'n afgetrokke wyse kennis: "Sy sien die vaal komberse oor die beddens en onder die komberse mense" (p. 19).

By die bed van 'n jong swartman word die geestelike gedistansieerdheid wat sy met Afrika ervaar, egter verbreek. Vir Hester word die sterk swart been soos 'n element uit die boswêreld, "'n stam wat groei uit die omhulsels van die wit lendelap wat tussen sy bene deur gevou is" (p. 20). Die beseerde is ook, skielik en ontstellend, man: "Die been ... eenkant toe uitgestoot op die bed, nakend, swart, glimmend, selfs in die roerloosheid kragtig van spier" (p. 20). Ook die matrone voel skielik bewus van die latente seksualiteit van die situasie en raak haastig. "Is dit die nakende lyf ," wonder Hester, "of die besef van die witvrou wat staar?" (p. 20; kursivering - SM). Die oomblik wanneer sy op 'n vreemde wyse seksueel aangetrek word deur die swartman, vind die opheffing van onverskilligheid plaas, die verdigting van belangstelling in die staar. 
Hiermee saam word nog 'n gedragspatroon, wat in samehang met die ruimtelike waarneming ontstaan het, verbreek. Hester was telkens van haar sweterigheid bewus; die ganse bosruimte is geteken in terme van hitte en lugspieëlings. Kort na die ontmoeting met die beseerde man nooi Piet haar na die skadu en sy antwoord: "Die son pla my nie meer so erg nie" (p. 20).

Kort hierna beleef Hester, in 'n koorsige droom, dat 'n beroep gedoen word op haar hulp aan die sterwende man in die vorm van 'n bloedskenking. Wanneer sy geroep word, weet sy wie haar bloed benodig, en dat betrokkenheid by die swartman betrokkenheid by die hele Afrikawêreld impliseer. Hulle hoort tot een, omvattende sfeer wat sy só herroep:

Sy sien die donker gesigte van die mense wat onder die bome lê ... dan sien sy die geel druppel vog op die punt om in te gaan in die are van die siek man op die hoë bed; dan weer die bloed wat drup uit die hoender se gekerfde nek (p. 22).

Aanvanklik veroorsaak die verset en vrees om met die koloniale ander kontak te hê by Hester 'n histeriese reaksie: "Maar hoekom ek? Hoekom nie jy nie?' Haar stem klim. 'Hoekom nie sy nie?'” (p. 23). Skok laat haar diégene wat haar tot die oortapping wil aanmoedig, vyandig ervaar: "Ook Piet is vir haar vreemd ... Die dokter se vrou ... is nou vir haar afstootlik" (p. 23; kursivering - SM).

Hierdie angs kan verband hou met die omstandighede van haar ontmoeting met die swartman, toe sy van sy seksualiteit bewus geword het. Schipper (1999:38) wys op die fisieke verskille wat die "African others" vanuit Europese waarnemingspunt toon en dat die viriliteit van die swartman as 'n bedreiging vir "ons" vroue beskou word. Ook by die winkel was Hester se waarneming van die "lyfvuil" teen die mure en die swartkinders wat "klou aan die pale" (p. 11) in ooreenstemming met die Westerse mite omtrent die Afrikamens waarna Schipper (1999:38) verwys: dat hulle "ander" liggaamsreuke het en liggaamlike ooreenkoms met diere (ape) toon.

As omstandighede Hester dwing om 'n keuse te maak, omdat sy klaarblyklik die enigste bereikbare mens met geskikte bloed is, demonstreer sy haar finale verset deur haar hele liggaam met karbolseep te was:

Sy skep die lou water in haar hande op, was haar gesig, gooi water oor haar nek, haar bors, haar oksels; sy vryf haar liggaam met haar nat, seepgesmeerde hande (p. 24). 


\subsection{Kruispad in identiteit}

In weerwil van Hester se emosionele verset is daar reeds op rasionele vlak die besef van die onafwendbaarheid van die geestelike transformasie wat in haar moes plaasvind: "Daar is iets onvermydeliks in hulle koms hierheen" (p. 24).

In die proses van identiteitskonstruksie speel die mens in sy geheel - verstand, gees én liggaam - 'n rol, sê Taljard (2002:46). Soos meermale in Joubert se werk word in "Bloed" ook van vroulike seksualiteit en vrugbaarheid gebruik gemaak as metafoor vir identifikasie en assimilasie. Die broeiende sfeer van die bos word voorgestel asof dit 'n aktiewe liggaamlikheid het: die grond ruik na "bevrugting" (p. 8), kosmos "klou" aan die boomstamme, sy ervaar die bos as "die omarming van die donker, stil swam" (p. 10).

Die eet van die piesangs word gelaai met seksuele suggestie: Hester loop met hulle "teen haar bors gedruk", sy skeur die skil los dat dit aan die stronk bly hang, "geel en bruin gestippel van buite, met 'n klam, melerige draderigheid van binne". Haar tande stroop die vrug uit die skil, "dit kom met 'n klein suiggeluidjie van die vrugpunt los" (p. 12). Ook met die slag van die hoender word 'n seksuele parallel gesuggereer, vanaf die spuit van die bloed oor die vroue se skoene tot waar "die hoender slap en wit oor haar [die swart vrou se] dye lê" (p. 14).

Later, wanneer Hester droom dat sy aan die swartman bloed skenk, word die spel met "bevrugting" en "verryking" afgerond. Bloedskenking impliseer verbintenis en ontvanklikheid, en uit die oortappingsdroom blyk duidelik in watter mate daar sprake is van "eenwording". Die gesublimeerde seksualiteit van die bloedoortappingsituasie gee 'n aanduiding van die totaliteit van oorgawe:

Sy hoor die gesteun van die swartman naby haar. Sy voel die swaar intrek van asem en dan die verslapping waarmee die kreun uitgepers word. Sy voel hoedat haar bors daarmee saam op en af beweeg ... Haar asem kan nie wegbreek van die ritme van die gewonde man se worstelende asemhaling nie. Selfs haar hart klop in die ritme van die asemhaling (p. 26-27).

Hierdie ervaring hou verband met die erkenning wat binne die koloniale diskoers gegee word aan die feit dat seksuele begeerte die keersy is van die afkeer wat die ander ras veroorsaak. Young (1995:115) sê:

The civilized European subject defined himself specifically through the exclusion of what is marked out as dirty and low. But 'disgust' 
always bears the imprint of desire. These low domains, apparently expelled as 'other', return as the object of nostalgia, longing and fascination.

Die betekenis van hierdie simboliese daad van Hester is veel groter as wat slegs die geslagsdaad sou kon wees - die droom dui op die onderbewussyn se aanvoeling van 'n identifiseringsproses wat plaasvind tussen Hester en haar omgewing, asook die "ander".

\subsection{Ervaring van hoort}

In "Bloed" word die proses van identifisering met Afrika - direk gekoppel aan 'n veranderde belewing daarvan as plek van positiewe ervaring - tot 'n hoogtepunt gevoer wanneer Hester in die nag ná die bloedoortapping na buite gaan. Sy soek liggaamlike kontak met die oeromgewing, staan "met haar lyf teen die stam gedruk sodat ... die boombas sy riwwe in haar vleis herhaal ... asof daar geen skeiding meer tussen haar en die boom is nie" (p. 27).

Sy word bewus van haar asemhaling:

Die beweging begin vanuit haar bors uitkring, word gedra na die volgende boom, na die groepies mense wat slaap onder die bome ... Die hospitaalgebou word ingetrek in hierdie stil in-enuitbeweging van haar asem, asof die digtheid van sy mure tot niet gaan en die siekes opgeneem word in hierdie groter stroom, hierdie in-en-uitbeweging van lewe (p. 18).

Seksualiteit en bloed kom dus uiteindelik neer op wisselwerking in 'n proses van groter eenwording, van asemhaling, "hierdie in-enuitbeweging van lewe", wat bind en verskille uitwis.

Die ervaring van te hoort bring 'n vrede wat Hester die hele nag laat buite bly (p. 28). Die konfrontasie met Afrika, wat op 'n "vroegwinteroggend, byna nog nag" (p. 7) begin het, is teen dagbreek afgehandel (p. 28). Op sikliese wyse is die proses van ekwilibrium, geestestryd en gemoedskalmte voltooi. Maar die vrou wat teen die einde wag op die dagbreek om die vorms van haar omgewing te "herken" (p. 28), is nie die vrou wat aan die begin "vreemd" gestaan het daarteenoor nie. Terwyl die tydsiklus die verhaal struktureel in 'n raam saamtrek, was haar geesteservaring, liniêr gesproke, 'n reis, 'n ontdekkingstog.

Daar word in die slotfase van Hester se reis afgewyk van die groot mitiese patroon van vertrek, inisiasie en terugkeer waarin Lyon (1996:279) gevind het die weergawes van reise dikwels aangebied word. Bestemming is geen terugkeer nie - Hester se belewing 
bevestig dat identiteit 'n konstruksieproses is. Ashcroft (2001:160) stel dit so: "What you do is related to where you are, what you have learned, and who you are with, a relationship that is ... reinforcing and interchangeably identifying."

\subsection{Postkoloniale ondermyning deur middel van intertekstualiteit4}

Op die allegoriese verhaalvlak loop die leser interessante parallelle raak met die Divina commedia waarin 'n geestelike pelgrimsreis voorgestel word en waarmee die Italiaanse digter, Dante Alighieri, onsterflike roem behaal het. Deur die verhaal losweg te skoei op aspekte van die Dante-gedig, word Westerse klassieke kultuurgoed hier intertekstueel toegeëien, maar terselfdertyd ook gekruis met Afrikagegewe en herverwerk in 'n Afrikaverhaal. Ashcroft (2001:30) sien hierdie werkwyse as 'n belangrike vorm van weerstand: die manier waarop gekolonialiseerdes die kulturele werktuie van die dominante kultuur en onderdrukker gebruik om hulleself te representeer en dus mag te verkry deur die meganismes van die oorheerser uit te buit, om vir hulself ruimte te skep.

Op Dante se reis word die digter gelei deur die hel en vagevuur en tot by die paradys, die hemel en die aanskouing van die Godheid self. Die reiservaring in die Divina commedia begin, ruimtelik gesproke, in 'n donker woud, soos ook Hester se reis begin. Die verdere parallellynigheid van Hester se ervaring met dié van Danté in sy gedig wys ek uit met behulp van Sinclair se vertaling, The divine comedy of Dante Alighieri (1971).

Volgens die digter (en volgens die Middeleeuse geloof) was die hel 'n ontsaglike en vuurwarm put, soos 'n tregter wat by die middelpunt van die aarde afgaan. Op die reis in "Bloed" is duidelike aanduidings van 'n hoogteverlies: vroegoggend begin hulle afdaal van die hoërliggende dele van die land (p. 7). Later in die dag sak hulle weer "in die wasige, warm leegtes af" (p. 14) en dit bring 'n loomheidslaappatroon by Hester, wat die reis deur die bos vir haar 'n soort

$4 \quad$ Volgens Anker (1990:167) behels intertekstualiteit die hele konteks waarbinne 'n bepaalde teks tot stand kom, die ander tekste wat 'n rol speel in die totstandkoming daarvan, tekste waarna direk en indirek verwys word, asook die tekste wat die leser in so 'n teks inlees; of waarmee hy sekere woorde, verwysings en implikasies assosiatief verbind, as gevolg van sy eie verwysingsraamwerk. 
reis deur 'n "onderwêreld" maak. "Dis die hitte", troos die dokter se vrou, "en die verandering van hoogte" (p. 26).

Oom Herrie neem hulle daglank al dieper en dieper die bos in, wat Dante se hel as middelpunt van die aarde in gedagte oproep. "Die hospitaal is nog dieper," (p. 11), antwoord oom Herrie op Hester se vraag (kursivering - SM).

Die Katolieke geloof maak voorsiening vir 'n plek tussen hel en hemel, die vageguur, wat reinig. In Divina commedia is dit die louteringsberg. Dante stel die berg voor in terme van al hoërwordende hange (Sinclair, 1971:13). Die plek van loutering blyk vir Hester die boshospitaal te wees. Vanaf die hospitaal se hek, waar Piet en Hester afgelaai word, is 'n grondpad wat oploop na die hospitaal, teen die hoogte uit (p. 17; kursivering - SM).

Teen Dante se louteringsberg ondergaan die siel baie smarte, maar daar is aanmoediging (verskeie engele), want dis die pad na die saligheid (Sinclair, 1971:9-13,109). Hester ondergaan die loutering/ suiwering van waarde-oordele in die hospitaal - die bewustheid van die swartman se seksualiteit, sy mens-/manwees, bring die krisis van koloniale oordele jeens die Afrikaboorling. Piet se teenwoordigheid in die verhaal kan in hierdie parallel verklaar word: in die tweede verhaaldeel is hy aanmoediger vir Hester op haar reis van loutering. Dit is hy wat haar aan die elmboog neem en na die badkamer stuur om haar te was voor die bloedoortapping wat op haar wag; dis ook hy wat saamloop na die hospitaal (p. 24).

Dante word in 'n diep slaap deur 'n engel tot aan die poort van die vagevuur gebring (Sinclair, 1971:121). Die dokter se vrou verkry in die verhaal 'n bepaalde engelagtigheid: sy is 'n bleek vrou - haar arms, bene en hals het 'n "klamwit kleur" (p. 20) - en is lig aangetrek, met sandale aan die voete en hare wat hang tot by haar middel. Sy praat op 'n "vertroulike, byna kinderlike manier"; sê onder andere: "Ek het ook al vir die gewondes bloed gegee" (p. 22) - 'n verdere toevoeging tot die attribute van engelagtige onskuld en bystand. Sy bly by Hester se bed totdat sy slaap en in die droom sê sy: "Hulle het my gestuur om jou te kom haal" (p. 23).

Hester se worsteling met die simbiotiese proses wat aan die gang kom tussen haar en die omgewing - die "toue" en "gewig" waarmee sy tot uitputtens toe in die droom veg wanneer haar bloed met die swartman s'n verenig - korreleer met die digter se worsteling op sy moeisame pad teen die louteringsberg (Sinclair, 1971:13). 
In die Divina commedia sny 'n engel met die punt van sy swaard die letter $P$ (vir die Latynse peccatum = sonde) op Dante se voorkop uit. Aan die einde van elkeen van die "kringe" van loutering (terasse teen die louteringsberg) staan nog 'n engel wat met sy vlerk oor die digter se voorkop streel en een van die P's wegvee, totdat al sy sonde uitgewis is (Sinclair, 1971:356). As Hester in samewerking met die dokter se opdrag haar liggaam en are probeer verslap om haar bloed na die swartman toe deur te laat, impliseer dit die oorkoming van haar verset om met die "primitiewe" wêreld kontak te hê. Die engelagtige figuur van die dokter se vrou buk oor Hester ná die ontsetting van haar emosionele vagevuur, haar hare val langs haar nek af voor haar bors en veeg rakelings by Hester se gesig verby (p. 26). Dit kan 'n parallel suggereer met die vlerk van die engel in Dante se werk, wat die teken van die laaste sonde wegvee.

\subsection{Saamgevat}

Die ondersoek na die wyse van die belewing van plek in "Bloed" het bewys gelewer van die dinamika waarmee die plekbelewing identiteitsbelewing bëinvloed. Die vraag "Wie is ek?" - gekoppel aan die identiteitskwessie "Waar hoort ek?" - lewer verrassend teenstrydige antwoorde wanneer dit op verskillende stadiums van die hooffiguur se reisbelewing in hierdie verhaal gestel word. Binne die vertelde tydsduur van 'n enkele dag word die vreemdeling in Afrika 'n mens wat hoort in Afrika. Hierdie aanpassingsproses staan in direkte verband met 'n drasties veranderde belewing van plek in die verhaal.

\section{Die ding in die vuur en "Bloed"}

Drie van die verhale in Riana Scheepers se debuutbundel Die ding in die vuur - deur middel van kruisverwysings 5 as kleiner geheel saamgebind binne die bundel as geheel - vind aansluiting by en vorm terselfdertyd ook 'n boeiende kontras met "Bloed".

5 Die kruisverwysings kom veral voor op die vlak van karakters en ruimte. In "Tweede kind" vind twee bevallings min of meer gelyktydig in 'n sendinghospitaal in die noorde van KwaZulu-Natal plaas en een van die babas kry koeimelk as surrogaat vir die oorlede moeder s'n. In "Drie sinvolle gesprekke" doen 'n vroulike antropologiestudent navorsing oor voedingspraktyke, onder andere die wanvoeding na aanleiding van kitsbabamelkadvertensies, by 'n plattelandse kliniek in die noorde van KwaZulu-Natal. Dieselfde student sowel as die koei word weer aangetref in "Dom koei". 
Word "Tweede kind", "Drie sinvolle gesprekke" en "Dom koei" saam gelees as gevolg van die eenheidskeppende elemente daarin, word die noukeurige leser getuie van hoe 'n reis op identiteitsvlak aangepak word. Deur fyn te let op die aspek van plekbelewing, word dit duidelik dat elkeen van dié drie verhale 'n fase uitbeeld in die wégdink uit die patroon van kontrastering en 'n "sáámdink van wêrelde: swart en wit, bygeloof en die rasionele soek na verklarings, stamgebruike en kliniese voortreflikheid" (Weideman, 1991). In die volgorde waarin hulle in die bundel geplaas is, verteenwoordig die verhale op 'n interessante wyse fases in die veranderende belewing van die eie identiteit, wat ooreenstem met die identiteitsreis in Elsa Joubert se "Bloed". Dis egter ook duidelik dat die vereenselwiging met Afrika in hierdie verhale minder volledig plaasvind as in "Bloed" en as ' $n$ minder dinamiese proses uitgebeeld word. Waar Joubert 'n enkele verhaal en treffende intertekstuele verbande gebruik in die uitbeelding van die kragtige aanpassingsreaksie in terme van pleken identiteitbelewing in die postkoloniale situasie, speel die aanpassingsproses hom in Scheepers se bundel op 'n meer subtiele wyse intratekstueel uit oor drie verhale heen. Kontrasterende tegniek dien om die gedeelde gegewe van karakters op 'n identiteitsreis in die gekose verhale van Joubert en Scheepers te beklemtoon en te nuanseer.

\section{Die ding in die vuur6}

\subsection{Onderweg in identiteit}

Die sendingstasie en hospitaaltjie in "Tweede kind" word vanuit 'n Europese verwysingsraamwerk gekleur as baken van oorwinning in die geestelike stryd teen "donker Afrika, blyplek van Umngoma en Isangoma" (p. 18). Die ingesteldheid op kerstening is sentraal ten opsigte van die sendelingsvrou se beskouing oor Afrika: "Ek ... verkondig saam met my man die geloof aan hierdie heidene" (p. 21). Terselfdertyd lê daar 'n duidelike distansiëring van die sendingobjek in die benaming sowel as haar negatiewe gedagte-inhoud oor hulle: "Sy het gewonder watter bakleiery dit nou weer was. Watter oopgekapte kop of gesteekte lyf kan dit wees dat die skepsel so skreeu" (p. 19). Omdat die moeder van die kind wat saam met hare gebore word, sterf en beesmelk nie met die swart kind akkordeer nie, word hy na die sendelingsvrou gebring om te soog. As die kind gemaak word, verwys na Scheepers (1990). 
aan haar borste moet drink, baklei sy: "Maar Here God, moet ek dan op só 'n manier hierdie skepsels se ellende deel?" (p. 21; kursivering - SM).

Die titel van die verhaal, "Tweede kind", kry 'n pynlike betekenis: twee is nie meer 'n telwoord nie, maar 'n rangordening, 'n ontneming. Die pasgebore kind wat die koeimelk nie kan inhou nie, is daarop geregtig om die borste te kry. As die vrou haar borste "vir die heidene gee" (p. 21), doen sy dit met wrewel en wanhoop. Sy eis dat God moet vergoed vir dit wat haar kind ontneem is: haar blonde kind moet sterker en groter groei met die melk van die Dexter as die swartkind met haar eie melk (p. 21).

In "Drie sinvolle gesprekke" openbaar die student, wie se belewing die drie gesprekke tot 'n eenheid saambind, 'n Afrika-ingesteldheid wat verskil van die angsvallige distansiëring deur die vrou in "Tweede kind". Sy motiveer haar aansoek om in die Mtunziniomgewing te werk in terme van ' $n$ vertroudheid en verbondenheid met dié wêreld: "Ek het hier grootgeword. Ek kan julle taal praat" (p. 39). Hiermee verwoord die student haar insig, dat die mense van 'n omgewing slegs geken kan word deur begrip vir hulle omgewing en die kragte wat hulle fisies en geestelik gevorm het. Die vrae van die swart staatsamptenaar in die landdroskanttoor op Mtunzini vrae soos: "Hoekom moet óns siek kinders u die kans gee om u geleerdheid te kry?" (p. 39) - dwing haar egter om in te sien dat sy nie heeltemal sonder ' $n$ eie agenda of patroniserende perspektief opheffingswerk op gesondheidsvlak wil kom doen nie.

Die gespletenheid in identiteit, die paradoksaliteit van uit te reik én af te wys, word herbevestig in die derde gesprek in hierdie verhaal. Op 'n navraag oor die moontlike aard van 'n navorsingsprojek oor voedingspraktyke by die Zoeloes in die KwaZulu-platteland, antwoord 'n man: "Seker maar oor hoeveel gallon hoesmedisyne die regering aan die blerrie swartes daar moet uitdeel, of so iets" (p. 41). Sy reaksie wys hoe konvensies en stereotipes in magsverhoudings steeds beeldvorming van en identiteitstoekenning aan die "ander" beïnvloed:

In "Dom koei" word die student getuie van die wrede kuisheidsgebruike van "tradisionele" Afrika. 'n Jong meisie word na die kliniek gebring, "die mik tussen haar bene 'n onherkenbare pappery van etter en rowe en tot barstens toe geswelde vlees" (p. 44). Terselfdertyd raak 'n koei buite die kliniek in die slap doringdrade van die omheining verstrik en die student tref die dier aan, "die dun vel om die uier en die spene stukkend en bloederig" (p. 45). In terme 
van die verwonding van die vroulike geslag word 'n parallel gelê tussen die koei wat "dom" onder sy redelose natuur moet ly en die jong meisie wat deur "dom"7 (vir die Westerling onverstaanbare en onmenslike) rituele gebruike van haar mense, lewenslank geskend word.

Die mense buite die kliniek wat gevra word om te help, kyk die student doodstil aan (p. 45) - 'n gelatenheid in stryd met die reaksie van die Westerling wat die lewensgang bevraagteken of daarin wil ingryp. Toe die meisie self by die koei neersak om die drade te begin loswoel, kry sy die beesreuk van die koei se natgeswete lies en die reuk wat van die sinkbuitetoilet af aangewalm kom. Dit ruik opeens vir haar "vars en skoon" (p. 45). Deur hierdie gewaarwording vind sy haarself bevry van die Europese situasiegebondenheid van waaruit sy die "opheffing" van Afrika wou onderneem, want sy begryp iets van wat sy hier beleef: tradisie/'n ouer generasie wat die "skade" aanrig (die meisie se verminking); die willose aanvaarding waardeur die skade al hoe groter word (die meisie se etterende wonde; die mense wat nie help om die koei los te maak nie). Deur die begrypende en ingrypende betrokkenheid (die loswoel van die doringdrade) kom daar 'n element van versoening.

Die student sien wel vanuit haar Europese verwysingsraamwerk die "domheid" van die situasie raak: "Jou simpel fokken dom koei!" skel sy (p. 45). Die "primitiwiteit" van bestaan in Afrika is egter meer aanvaarbaar, nie weersinwekkend soos dit pas nog was nie - die reuk is "vars en skoon", omdat sy begryp én aktief optree.

Die einde van die bundel bevestig dat die identiteitsbestemming in Die ding in die vuur verskil van die volledige vereenselwiging met Afrika wat plaasvind in "Bloed". In die laaste verhaal in die bundel sit die student in die kantoor van die professor in Afrikatale en hy vertel haar 'n storie in 'n taal "wat ek verstaan, en wat ek gebroke kan praat, maar waarin ek nooit sal kan droom, of huil, of sing, of verhale sal kan vertel nie" (p. 84).

Tog word in elkeen van Scheepers se drie verhale 'n duidelik onderskeibare fase in identiteitsvereenselwiging met Afrika uitgebeeld. In "Tweede kind" spreek die vrou se verset teen die oerverbintenis

Die term dom, hier verwysend na die onkunde van die plattelandse samelewing om steeds die verminking en ontering van vroue deur die besnydenisritueel te sanksioneer, word deur Visagie (1999:113) gelees as draer van 'n sterk kritiese perspektief op die aftakeling van die vroulike liggaam deur patriargale tradisies wat voortleef binne die Afrikakultuur. 
met die kontinent baie duidelik. In "Drie sinvolle gesprekke" is ' $n$ mate van assosiasie aanduibaar, ondanks die feit dat daar steeds, byna onbewustelik, 'n geneigdheid tot distansiëring bestaan. "Dom koei" beeld 'n duidelike mate van "oorgawe aan die paradokse van ons Westerse en Afrika-bestaan [uit], in stede van die meer irrasionele Afrika-elemente in onsself te onderdruk" (Hambidge, 1990).

\subsection{Topologiese opposisies: rigtingduiders ten opsigte van identiteitsaanpassing}

Deur die weergawe van sterk sintuiglike waarnemings - die geure, kleure en gevoel van 'n landelike bestaan - word prominensie aan die aspek van die plekbelewing in Scheepers se verhale gegee. Hierdie onmiddellikheid van die fisieke ervaring word aangewend as bepalende strukturele element. Die oog val steeds op die voorgrond, wat met groot noukeurigheid beskryf word, maar die effek en die boodskap van die teks kom juis deur die kontras met 'n ander toneel of situasie tot stand. Hierdie ruimtelike teenstellings is duidelike aanduiders van die rigting waarin daar ten opsigte van identiteitsbelewing beweeg word.

In "Tweede kind" is die landelikheid van die Zulu-woongebied in die omgewing van die Ndunu-heuwels op die voorgrond in die vertelde ruimte. Ná die wydlopige beskrywing van die buiteruimte (p. 19) word egter tot die essensie van die verhaal gekom in die binnetoneel in 'n hospitaal - die toneel waartydens die witvrou se bittere verset teen die aanspraak van Afrika op haar gestalte kry in die gebelgde woorde: "noudat ek my borste vir die barbare gegee het" (p. 21).

In "Drie sinvolle gesprekke" word dieselfde omgewing reeds deur die student se aansoek om in die Mtunzini-gebied op die KwaZuluplatteland navorsing te doen, in die leser se gedagte gekonstrueer. Die aansoekvorm van die meisie impliseer reeds die navorsingsruimte wat in ' $n$ vorige verhaal gekonkretiseer is. Op dieselfde wyse impliseer die gesprek oor babavoeding wat tussen die student en die suster in die kliniek plaasvind, die Afrikaruimte van waaruit die swart vroue met hulle ondervoede kinders die kliniek binnekom. Die gradedagtoneel, in die totaal verwyderde ruimte van 'n moderne lugverkoelde universiteitsentrum, dramatiseer egter die vereenselwigingsproses met Afrika wat besig is om plaas te vind: die student het betrokke geraak, terwyl ander haar navorsing onder die "blerrie swartes" (p. 41) in totale apatie bejeën. 
Daar word in "Dom koei" pertinent op die primitiewe van die KwaZulu-gebied gefokus: "Die kliniekgebou is 'n witgekalkte gehuggie op 'n oopgetrapte stuk rooigrond. Die werf is omhein met doringdraad wat plek-plek so slap hang dat dit nooit die buurt se bokke kon uithou nie. In die een hoek van die werf is 'n buite-toilet met 'n dik stinklug en 'n sinkplaatdak wat met groot klippe vasgepak is" (p. 43).

Van hierdie ruimte is die student egter geskei deur die kliniekmuur. Sy is binne haar onmiddellike werkruimte gevul met ondervoede en siek mense. In skerp kontras met die binneruimte, waarin konfrontasie met die grusaamheid van bepaalde Afrikagebruike haar met mislikheid vul (p. 45), staan die buitetoneel met die koei in die doringdraad, toe die begrip omtrent die konteks waarin die dinge staan, daag, en sy die reuk van die bees skielik sonder weersin ervaar. Die student wat in "Drie sinvolle gesprekke" probeer het om die gesondheidskwessie in Afrika van binne die kliniek te beredder, moet uiteindelik uit die kliniek uitgaan om daar buite individueel, reddend en aktief in te gryp, as teken van 'n identiteitsvereenselwiging met die vasteland waarop sy leef. Die topologiese struktuur van hierdie drie verhale steun dus baie duidelik die proses van perspektiefverandering op en identifikasie met Afrika.

\subsection{Fokalisasie: die filter wat plekbelewing kleur}

Daar is heelwat omtrent die belewing van plek af te lei uit die wyse waarop waarneming in en van daardie plek geskied. Soos blyk uit die navorsing van Pratt (1992) en Ryan (1996), speel perspektief/fokalisasie 'n groot rol binne die koloniale en postkoloniale diskoers met betrekking tot die representasie van sowel die ruimte as die ander.

In die soeke na 'n term om die waarnemende karakter se houding ten opsigte van wat waargeneem word mee vas te vang, stel Liebenberg (1996:197) voor dat die term filter, wat deur Chatman geskep is, as alternatief kan dien vir fokalisering in die sin waarin Bal8 die term gebruik. Chatman (1986:196) doen aan die hand: "The narrator can elect to tell a part or the whole of a story neutrally or 'from' or 'through' one or another character's consciousness. This function should I think be called 'filter'." Hierdie definisie van filter

Volgens Bal (1980:108) word fokalisering gedefinieer as "de relatie tussen de gepresenteerde elementen en de visie van waaruit deze worden gepresenteerd". By die term fokalisasie word die partydigheid ("point of view" in die sin van die fokaliserende karakter se houding, begrip, ideologie of manier van dink) dus ook betrek. 
pas myns insiens goed by Bal se gebruik van fokalisering, wat te make het met die wyse waarop die karakter se siening of houding die gegewe kleur.

In Die ding in die vuur word karakters en hulle waarnemings (sintuiglik, maar ook psigologies en ideologies) dikwels gejukstaponeer. Nuwe insigte en sentrale onthullingsmomente ontstaan uit die verskillende perspektiewe op 'n saak.

'n Faktor wat direk verband hou met die belewing van plek in hierdie verhale, is die rede vir die karakters se teenwoordigheid in afgeleë Afrika: die sendingtaak in "Tweede kind" en gesondheidswerk in "Drie sinvolle gesprekke" en "Dom koei". In "Tweede kind" word vanuit twee heeltemal verskillende ideologiese oogpunte na die sendingtaak gekyk. Die sendeling se vrou fokus op die toewyding aan hulle roeping:

Here, hier staan jou kerk op die plek waar Zoeloeland se toordokters eers almal in hulle grashutte saamgehurk was. Hier staan jou kerk op die slagveld waar Dinizulu en Zibephu mekaar met die assegaaie uitgemoor het (p. 21).

Uit die oogpunt van die sendingobjek lyk die rapportering anders:

Nie eers die keer toe hy [die sendeling] hier by die stat aangekom het met sy perd ... het hulle iets met hom te doen gehad nie. Hulle het hom van ver sien aankom en toe het hulle doodstil in die donker hutte ingegaan en inasem gewag ... totdat hy opgehou het met roep en ver weg was ... Hulle sal nie naby hom kom nie. Hom nie eens aankyk nie ... Die Isangoma sien en hoor en weet van elke asemteug van die stat (p. 20).

Die effek is dat in die presentasie van die ontmoeting van Afrikaan en Europeër juis die in-stryd-verkeer van primitiwiteit en beskawing onthul word.

In "Drie sinvolle gesprekke" word die taak van gesondheidswerk eweneens uit kontrasterende oogpunte bekyk. "Ek gaan wérk. Ek gaan in moeilike omstandighede werk. Ek doen dit vir julle óók" (p. 38), is die perspektief van die student. In die oë van die amptenaar sien sy egter die afkeer van die blanke wat vanuit verwesterse stellinginname Afrika wil kom transformeer: "Van alle menslike wesens is sy een van die laagste op die hiërargie van menswaardigheid. 'n Ongetroude, lui vrou sonder kinders, wat studeer. En wit" (p. 38-39). 
In "Dom koei" is daar die jukstaponering van perspektiewe op die geslagtelike verminking van die meisie. Wanneer sy na die kliniek gebring word, skel suster Ngomezulu op haar mense: "Uit! Uit hier, julle barbare!" (p. 44) en stoot hulle hardhandig in 'n bondel by die deur uit. In teenstelling met die afkeer in suster Ngomezulu se houding - 'n duidelike bewys van haar distansiëring van diegene wat bly vasklou aan skadelike en vroue-onterende tradisionele gebruike - verraai die student se waarneming slegs ontsetting en intense simpatie:

Die suster knip die stukke tou waarmee die toegroeiende skaamlippe vasgewerk is, versigtig los. Stukke rou weefsel wat soos rowe aan die growwe tou vassit, kom ook los. Die wonde begin bloei.

Die meisie lê roerloos ... Sy huil geluidloos, sonder trane. Haar oë is groot en oop, soos 'n dier s'n (p. 45).

Hierdie heeltemal direkte konfrontasie met van die mees "irrasionele" Afrika-aspekte skok die student tot ingrype. Sy is nie langer die tongklikkende evalueerder van die hopelose volkekundige situasie nie - op haar knieë in die Afrikastof en -sweet, langs bebloede koeispene, is sy betrokkene. In háár ontmoet die wêrelde van Europeër en Afrikaan dus in dié oomblikke.

Noukeurige aandag aan ruimtebeelding deur middel van personeteks ${ }^{9}$ maak die effek van die filter nogmaals duidelik. Uit brokke personeteks blyk op 'n subtiele wyse die veranderde plekbelewing, gekorreleerd met 'n gesindheidsverandering jeens Afrika, soos wat dit oor die drie verhale heen geskied.

Ruimtebeelding in "Tweede kind" is feitlik uitsluitlik 'n vertellersaangeleentheid. Teen die verhaaleinde deel die sendeling se vrou egter ook by wyse van haar houding hierin:

Ek gee nie om dat my seuns saam met die abantwana swem nie ... Ek gee nie om as hulle by die strooise speel en na stroois ruik nie ... Here, ek is 'n meisie uit die Hugenote-vallei, maar ek sal hier werk saam met my man (p. 21; kursivering $\mathrm{SM})$. 
Diskreet word aan die Here gestel dat sy die grootword van haar seuns saam met die kinders van die plaaslike bevolking verduur, omdat haar gesin ter wille van Hom daar is. Dis 'n subtiele, maar duidelike geestelike distansiëring van dié wêreld met sy modderige riviere en misvure.

'n Enkele stukkie personeteks, in diens van ruimtebeelding, word naby die middel van "Drie sinvolle gesprekke" aangetref:

Die meisie kyk [deur die kliniekvenster] na die mure wat met baie jare se stof en reënstorms 'n vuil aarde-kleur gekry het, die winkelstoep met die dromme en sakke, die dak wat aan die een kant ingeduik het, die verweerde advertensies wat lank terug teen die mure geverf is (p. 39).

Wat hierdie waarneming van die waarnemer verraai, is 'n soort neutraliteit: sonder blaam of ontnugtering aanskou sy die verwering deur die elemente, wat met verloop van tyd in hierdie skraps-ontwikkelde deel van Afrika plaasgevind het. Dit word bevestiging van die mate van identifikasie met Afrika wat sy in die gesprek in die landdroskantoor verwoord het: "Ek het hier grootgeword" (p. 39).

Ook in "Dom koei" domineer die vertellerteks in die konstruksie van konkrete ruimte. Tog berus die waarneming van die enkele werftonele by die student. In die laaste paragrawe, wanneer sy die koei uit die draad bevry, verraai die besondere sintuiglike intensiteit van haar waarneming die veranderde belewing van die onmiddellike Afrika-omgewing. Die aanvaarding van die dualisme in haar identiteit word dus in die personeteks geopenbaar.

\section{Samevatting}

Waar in Joubert se verhaal reeds getoon is op watter dinamiese wyse die belewing van plek die belewing van identiteit beïnvloed, is in Scheepers se verhale ook bewys gevind vir die subtiliteit waarmee die verandering in identiteitbelewing plaasvind en hoe subtiel die belewing van plek in hierdie proses ingeweef is.

In die verhale is demonstrasie gevind van die ontginning van 'n verskeidenheid moontlikhede, by wyse waarvan die direkte invloed van plekbelewing op identiteitbelewing gereflekteer word. In Joubert se verhaal, "Bloed", word 'n geestelike "kragtoer" uitgebeeld in terme van identiteitsaanpassing in Afrika; ' $n$ proses wat deur 'n drasties veranderde belewing van plek gerugsteun word. By die heroriënteringsproses ten opsigte van identiteit in hierdie verhaal word die mens in sy geheel - verstand, gees én liggaam - betrek en is 
elkeen van die kernaspekte in identiteitskonstruksie - geslag, klas, ras en seksualiteit - betrokke.

In die verhale van Scheepers wat by die ondersoek ingesluit is, vind die identiteitsaanpassing minder volledig en op minder drastiese wyse plaas. Sake wat subtiel verband hou met die belewing van plek, word in dié verhale rigtingduiders van waarheen daar op identiteitsvlak beweeg word - veral die topologiese struktuur van die verhale en die effek van die filter-fokalisering steun die proses van perspektiefverandering op en identifikasie met Afrika.

Die bewyse van die karakters se vermoë om in terme van plek- en identiteitsbelewing by 'n situasie aan te pas, spreek van die positiwiteit en soepelheid waarmee die postkoloniale mens op sy/haar situasie reageer. Die uitbeelding van identiteitsbelewing, as ingebed in plekbelewing, word in hierdie ondersoek uitgewys as 'n literêre strategie wat in Joubert se werk reeds ten minste vir vyf-entwintig jaar in gebruik is. Dit is dus geen nuwe werkwyse nie, maar een waarmee Joubert sowel as Scheepers op betekenisvolle wyse meewerk aan die opstel van die postkoloniale kontradiskoers wat nie meerderwaardig en verdrukkend is in die representasie van die kulturele "ander" nie.

\section{Geraadpleegde bronne}

ANKER. J. 1990. "Paddaksioom" en intertekstualiteit. Unie, 87(4):167-169.

ASHCROFT, B. 2001. Post-colonial transformation. London. Routledge.

BAL, M. 1980. De theorie van vertellen en verhalen: inleiding in de narratologie. Muiderberg: Coutinha.

BEUKES, S.M. 1982. Die skryfkuns van Elsa Joubert. Pretoria: Universiteit van Pretoria. (M.A.-verhandeling.)

BRINK, A.P. 1987. Vertelkunde. Pretoria: Human \& Rousseau.

CHATMAN, S. 1986. Character and narrators: filter, center, slant and interestfocus. Poetics Today, 7(2):189-204.

HAMBIDGE, J. 1990. Verhale met vuur in dié debuut. Beeld: 10, 26 Nov.

HUNTER, E.S. 1990. A sense of place in selected African works by Doris Lessing. Kaapstad: Universiteit van Kaapstad (D. Phil.-proefskrif.)

JOUBERT, E. 1980. Melk. Kaapstad: Tafelberg.

JOUBERT, E. 1997. Gordel van smarag. Kaapstad: Tafelberg.

LIEBENBERG, W. 1996. Fokalisering: bottelnek of filter? Tydskrif vir Literatuurwetenskap, 12(1/2):187-206.

LYON, J.L. 1996. A taxonomy of nature writing: the ecocriticism reader. Athens: University of Georgia Press.

PRATT, M.L. 1992. Imperial eyes: travel writing and transculturation. London: Routledge.

RYAN, S. 1996. The cartographic eye: how explorers saw Australia. Cambridge: Cambridge University Press.

SCHEEPERS, R. 1990. Die ding in die vuur. Pretoria: HAUM-Literêr. 
SCHIPPER, M. 1999. Imagining insiders: Africa and the question of belonging. London: Cassell.

SINCLAIR, J.D. 1971. The Divine comedy of Dante Alighieri. London: Oxford University Press.

TALJARD, M.E. 2002. Herkoms en identiteit in Die swye van Mario Salviati (Etienne van Heerden) en De naam van de vader (Nelleke Noordervliet). Potchefstroom: PU vir CHO. (M.A.-verhandeling.)

VILJOEN, H., Lewis, M. \& Van der Merwe, C.N. 2004. Learning about space and about ourselves (In Viljoen, H. \& Van der Merwe, C.N., eds. Storyscapes: South African perspectives on literature, space and identity. New York: Peter Lang. p. 1-22.)

VILJOEN, L. 2002. "Die kleur van mens": Antjie Krog se Kleur kom nooit alleen nie (2000) en die rekonstruksie van identiteit in post-apartheid Suid-Afrika. Stilet, 14(1):20-49.

VISAGIE, A. 1999. Subjektiwiteit en vroulike liggaamlikheid in enkele tekste van Riana Scheepers en Antjie Krog. Literator, 20(2):107-121.

WEIDEMAN, G. 1991. Die ding in die vuur: R. Scheepers. Boekresensie. De Kat, 6(9):92-95.

WHITEBROOK, M.W. 2001. Identity, narrative and politics. London: Routledge.

YOUNG, R.C. 1995. Colonial desire: hybridity in theory, culture and race. London: Roulledge.

\section{Kernbegrippe:}

identiteitskonstruksie

Joubert, Elsa

plekbelewing

postkoloniale aanpassing

Scheepers, Riana

\section{Key concepts:}

construction of identity

experience of place

Joubert, Elsa

postcolonial adaptation

Scheepers, Riana 